\title{
ANNUAL MAY-DAY BIRD COUNT, SASKATOON
}

\author{
by J. F. Roy, 120 Maple Street, Saskatoon
}

This year, 49 observers (seven more than in any previous year) in nine parties established a record of 157 species, 11 more than on May 25, 1968 , when 42 observers recorded 146 species. As more observers get out in the field and leaders become increasingly familiar with the area, the species total continues to climb. The table below provides a summary of the May-day counts since their inception in 1957. Note the change in area covered since 1961 . The count is now taken in a square block consisting of 100 townships (3,600 square miles) centering on Saskatoon.

\section{Summary of May-day counts in Saskatoon area}

\section{Date}

Area covered
No. of

No. of Observers Parties Species
May 26, 1957

May 25, 1958

May 24, 1959

May 23, 1960

May 22, 1961

May 26, 1962

May 18, 1963

May 23, 1964

May 15,1965

May 14, 1966

May 27, 1967

May 25, 1968

May 24, 1969

Circle, $\begin{gathered}7 \frac{1}{2} \text { mile radius } \\ " \\ " \\ \text { " }\end{gathered}$

Circle, 25 mile radius

Study area, 3600 sq. mi.

98

9

9

"s

,

24
14
13
14
21
24
25
20
22
31
29
42
49

14

13

14

21

24

25

20

22

31

29

42
104

88

112

99

100

127

137

129

137

140

145

146

157
Last year we attempted to count all individuals of 18 species and the first 25 of every other species. This year, in an effort to simplify the counter's task, we made a full count of only nine species: Mountain Bluebird, Common Crow, Eastern Kingbird, Western Kingbird, Black-billed Magpie, Horned Lark, Western Meadowlark, Shorteared Owl, Robin, and Loggerhead Shrike. For every other species count. ing stopped when a total of 25 individuals was reached, except that all flocks of 50 or more were recorded. The only species for which any kind of valid comparison of numbers can be made are those which numbered fewer than 25 in both years, and the bluebird, crow, Eastern Kingibird, Western Kingbird, magpie, meadowlark and shrike, which were completely counted in both 1968 and 1969 .
For the first time, each of the participating parties was asked to make a water-area count, a modest beginning in the attempt to measure at least one kind of habitat, in this instance that suited to young water birds. Each group counted all water areas (including streams, dugouts and borrowpits) visible within 110 yards on either side of a 24-miles stretch of all-weather road. We hope to continue this type of count, perhaps extending it in 1970 to include groves of trees along a similar length of road.

Records of interest this year include the sighting of two Common Loons, 34 Western Grebes (compared with 12 last year), and 23 Bufflehead, all of them species likely to be seen more often now that reservoins like Blackstrap and Brightwater are full. A marked increase in Short-eared Owl 
(32 compared with one in 1968) and Marsh Hawk population (96 compared with 53 in 1968) is indicated. Six hawk nests (two Cooper's, two Red-tailed and two Marsh) and ten owl nests (four Great Horned, four Long-eared, one Short-eared and one Saw-whet) were recorded on the day of the count. Among the shorebirds were several rarities: two Piping Plovers, eight Knots (including a flock of seven in the NW quadrant), two Dunlins and 25 Buff-breasted Sandpipers. 1450-+ Northern Phalaropes were seen, including more than 1,000 in the $\mathrm{NE}$ quadrant. A marked reduction in Lark Buntings is apparent, five being noted compared with $210+$ in 1968. Only one Downy Woodpecker was counted, and not a single Black-capped Chickadee turned up on the count (although family groups were again in evidence by late June). The two Red-breasted Nuthatches were unusually late. Despite the impressive number of species recorded, no new records were added to the regional list.

Weather (May 24, 1969): Temperature at 5:00 a.m. $48^{\circ} \mathrm{F}$; high during the day $73^{\circ} \mathrm{F}$; at $8: 00$ p.m. $51^{\circ} \mathrm{F}$. Sky cloudy, averaging $7 / 10$ cover during the day. Wind SSE 10-15 mph.

\section{SPECIES LIST}

Common Loon, 2 ; Red-necked Grebe, 4 ; Horned Grebe, $102+(3$ nests $)$; Eared Grebe, 35 (1 nest) ; Western Grebe, 34 ; Pied-billed Grebe, 13 ; Double-crested Cormorant, 2 ; Great Blue Heron, 4; American Bittern, 1; Whistling Swan, 1 ; Canada Goose, 5 ; Mallard, $222+(3$ nests, 8 broods) ; Gadwall, $82+(1$ nest) ; Pintail, $220+(1$ nest, 4 broods $)$; Green-winged teal, $53+$; Blue-winged teal, $170+(2$ nests $)$; American Widgeon, 142+; Shoveler, 203+; Redhead, 84; Ring-necked Duck, 22 ; Canvasback, 106+; Lesser Scaup, 165+; Common Goldeneye, 6; Bufflehead, 23 ; Ruddy Duck, 111+; Common Merganser, 1; Sharp-shinned Hawk, 1; Cooper's Hawk, 5 (2 nests) ; Redtailed Hawk, 17 (2 nests); Swainson's Hawk, 19 ; Rough-legged Hawk, 2 ; Marsh Hawk 96 (2 nests); Pigeon Hawk, 3; Sparrow Hawk, 8; Ruffed Grouse, 7 (1 nest); Sharp - tailed Grouse, $83+$; Ring-necked Pheasant, 12 ; Gray Partridge, 36 ; Sandhill Crane, 5; Sora, 28; American Coot $182+(46+$ nests $)$; Piping Plover, 2; Killdeer, 118+ (1 nest) ; American Golden Plover, 15 ; Black-bellied Plover, 123+; Ruddy Turnstone, 27+; Common Snipe, 3; Long.billed Curlew, 2 ; Upland Plover, 6 ; Spotted Sandpiper, 46; Solitary Sandpiper, 1; Willet, $60+$; Greater Yellowlegs, 1; Lesser Yellowlegs, 11; Knot, 8; Pectoral Sandpiper,
72; White-rumped Sandpiper, 17t; Baird's Sandpiper, $14+$; Least Sandpiper, $4+$; Dunlin, 2+; Dowitcher, 4 ; Stilt Sandpiper, $347+$; Semipalmated Sandpiper, 236; Buff-breasted Sandpiper, 25+; Marbled Godwit, 59; Sanderling, 28+; Avocet, 287 (6 nests); Wilson's Phalarope, $246+$; Northern Phalarope, $1450+$; California Gull, 22; Ring-billed Gull, $75+$ - ; Franklin's Gull 135+; Common Tern, 12; Black Tern, $537+$; Rock Dove, $84+$; Mourning Dove, 85+ ; Great Horned Owl, 6 (4 nests): Burrowing Owl, 1; Long-eared Owl, 8 (4 nests) ; Short-eared Owl, 32 (1 nest) ; Sawwhet Owl, 1 (1 nest) ; Common Nighthawk, 9; Ruby-throated Hummingbird, 1; Belted Kingfisher, 1; Yellow-shafted Flicker, 55 (2 nests); Yellow-bellied Sapsucker, 6 (1 nest) ; Hairy Woodpecker, 3 ; Downy Woodpecker, 1 ; Eastern Kingbird, 94; Western Kingbird, 39; Eastern Phoebe, 1; Least Flycatcher, 95+; Western Wood Pewee, 3; Olive-sided Flycatcher, 1 ; Horned Lark, 238+ ; Tree Swallow, $275+(50$ nests $)$; Bank Swallow, $230+$; Barn Swallow, 184+ ; Cliff Swallow, 7 ; Blue Jay, 4 ; Purple Martin, 4; Black-billed Magpie, 278; Common Crow, 633 (2 nests); Red-breasted Nuthatch, 2 ; House Wren, $64+$; Long-billed Marsh Wren, 1; Short-billed Marsh Wren, 1; Catbird, 13; Brown Thrasher, 53; Robin, 151 (1 nest); Hermit Thrush, 1; Swainson's Thrush, 25; Gray-cheeked Thrush, 4; Veery, 6; Mountain Bluebird, 71 (1 nest); Sprague's Pipit, 14; Loggerhead Shrike, 71; Starling, $144+$ (4 nests) ; Red-eyed Vireo, 3; Warbling Vireo, 38; Tennessee Warbler, 8; Orangecrowned Warbler, 2; Yellow Warbler, 130+; Myrtle Warbler, 5; Northern Waterthrush, 1; Mourning Warbler, 3; Yellowthroat, 9; American Redstart, 1; House Sparrow, 174+ (1 nest) ; Bobolink, 16 ; Western Meadowlark, 683; Yellow-headed Blackbird, 194+; Redwinged Blackbird. 236+; Baltimore Oriole, 70 ; Brewer's Blackbird, 196+; Common Grackle, 30 ; Brown-headed Cowbird, 258+; Rose-breasted Grosbeak, 7 ; American Goldfinch, 87+ ; Rufous-sided Towhee, 44+ ; Lark Bunting, 5 ; Savannah Sparrow, 108+; Grasshopper Sparrow, 1; Baird's Sparrow, 15 ; LeConte's Sparrow, 3 ; Vesper Sparrow, 119+; Lark Sparrow, 5; Slate-colored Junco, 1; Chipping Sparrow, 101+; Clay-colored Sparrow, $170+$; White-crowned Sparrow, 4 ; Whitethroated Sparrow, 23: Lincoln's Sparrow, 2; Song Sparrow, 98+; McCown's Larkspur. 11; Lapland Longspur, $1050 \pm$ Chestnut-collared Longspur, $53+$.

\section{CHRISTMAS BIRD COUNT} 1969

List the number of each bird species seen on the ONE BEST DAY between Saturday, December 20, 1969 and Thursday, January 1, 1970 (inclusive). In addition, list other species observed during the above dates. See March 1969 Blue Jay for other details. Send reports as soon as possible to

Mrs. Mary Houston, 863 University Drive, Saskatoon. 